\title{
EFFECT OF USING FISH BASINS DRAINAGE WATER, MULCHING AND WATERING REGIME ON CABAGE CROP PROPERTIES UNDER DRIP IRRIGATION SYSTEM
}

\author{
Elmetwalli ${ }^{1}$, A. H and Amer M. M.
}

\begin{abstract}
Water scarcity in Egypt increased with rapidly population growth which represents a great challenge for the Government. The reuse of drainage water produced from various agricultural sources including cultivated lands and fish farming systems could a robust solution for horizontal expansion of cultivated area. This research aimed to assess the feasibility of using the drainage water of fish farming basins to irrigate cabbage crop. Three different watering regimes (100\%, $80 \%$ and $60 \%$ ETc) and two types of water (canal water and fish farming drainage water) were investigated under two conditions (mulching with rice straw and without mulching). The results demonstrated that drainage water of fish increased the yield of all cabbage components. The combination of $100 \%$ ETc, and drainage water of fish with mulching produced the highest head yield of 197.5 $\mathrm{Mg} \mathrm{ha}^{-1}$ comparing with other treatments. Fish water increased yield by 1.7, 49.3 and 30.6\% under 100, 80 and 60 ETc respectively. Marketable head yield, head diameter and head height had the same trend. The highest values of Marketable head yield, head diameter and head height were $167.9 \mathrm{Mg} \mathrm{ha}^{-1}, 70.4 \mathrm{~cm}$ and $59.5 \mathrm{~cm}$, respectively. The results also showed that low watering regime (60\% ETc) resulted less head yield and other yield components regardless the influence of water type and using mulching.
\end{abstract}

Key words: fish, water, regime, mulching, drip, irrigation and cabbage

\section{INTRODUCTION}

$\Gamma$

The River Nile is the backbone of Egypt's industrial and agricultural sectors and is the primary source of drinking water for most of the population. Rapidly population growth and rapid economic development in Egypt, pollution and environmental degradation are

1) Assoc. prof. Agric. Engi., Fac. Agric., Tanta University, Egypt

2) Assis. prof. Agric. Engi., Fac. Agric., Tanta University, Egypt 
decreasing water availability in the country and thus the optimum use of water resources is fundamentally crucial. In this context, exploring robust solutions to some aspects of Egypt's water-scarcity problem is necessary. This includes for example the use of water in agriculture more efficiently, desalinating brackish water, and to reuse low quality water produced from agricultural lands and fish farms.

Previous studies showed the importance of the reuse of drainage water of fish farming systems to face the challenge of water shortage. For instance, Masser et al. (1992) and Abdelraouf et al. (2014) revealed that the reuse of drainage water of fish farming systems is considered an alternative and a step forward to overcome the challenge of water scarcity. Wood et al. (2001) assessed the potential of fish ponds drainage water to irrigate wheat and pointed out that the fish ponds drainage water can enhance wheat yield and save in the mean time the amount of fertilizers required for wheat production. Okasha et al. (2016) quantified the effect of water type (canal water and drainage water of fish farming systems), and nitrogen rate on the yield of soybean under sprinkler irrigation system and concluded drainage water of fish farms produced higher soybean yield and water productivity comparing with canal fresh water. Sikawas and Yakupitiyage (2010) assessed the potential of using drainage water of fish ponds to grow lettuce and found that filtering fish ponds drainage water has the effective use for the hydroponic lettuce production. Attafy and Elsbaay (2017) used fish effluents to drip irrigate lettuce crop under various nitrogen fertilization levels and found that fish drainage water led to higher lettuce yield, nitrogen productivity comparing with canal fresh water.

The protocol of feeding air-breathing fish ends up with accumulation of fecal, feed and excretory effluents in fish basins water (Yi et al., 2003 and Porrello et al., 2005) these effluents rich in nutrients and elements that are fundamentally important for crop growth can provide a robust source for fertilizing agricultural crops. Lin and Yi (2003) concluded that the use of catfish waste water to irrigate crops has been demonstrated among the most cost-effective effluent treatment option. 
The overall aim of this research study was to assess the potential of reusing drainage water of fish farming systems as an alternative successful source of water and nitrogen to irrigate cabbage. The objectives of this research study were to i) study the impact of the reuse of drainage water of fish farming basins on cabbage yield, ii) increase nitrogen productivity of cabbage crop and iii) increase cabbage head total yield and thus water productivity.

\section{MATERIALS AND METHODS}

\section{Study area and soil analyses}

A field experiment was conducted in summer growing season of 2018 to assess the potential of reusing the drainage water of fish basins to irrigate cabbage crop. The experiment was executed at the Horticulture Research Station, Faculty of Agriculture, Kafrelsheikh University. The research aims to use an alternate source of fresh water which is rich in nitrogen and thus reduce the amount of fertilizers required for the crop. The experimental soil was classified as a clay soil with $1.27 \mathrm{~g} / \mathrm{cm}^{3}$ average soil bulk density. The volumetric water content values were measured using pressure membrane as 44.5, and $20.85 \%$ at field capacity, and wilting points, respectively. The mechanical analysis of the experimental soil including sand, silt and clay percents is detailed in Table (1). Table (2) details the chemical analysis of the experimental soil including anions, cations, EC, $\mathrm{pH}$ at various soil depths. Cabbage was transplanted in the first week of May and the growing season lasted to 115 days after transplanting. Nitrogen fertilization in the form of ammonium nitrate was added at the recommended rate $\left(285 \mathrm{~kg} \mathrm{~N} \mathrm{ha}^{-1}\right)$ in three equal doses at 30 45 and 60 days after transplanting. A pressure differential tank was used for the application of nitrogen fertilizer.

Table (1): Mechanical analysis and some soil physical properties

\begin{tabular}{|c|c|c|c|c|c|c|c|c|}
\hline \multirow{2}{*}{$\begin{array}{c}\text { Depth, } \\
\text { cm }\end{array}$} & \multirow{2}{*}{$\begin{array}{c}\rho_{b}, \\
g / \mathbf{c m}^{-3}\end{array}$} & \multirow{2}{*}{$\underset{\%}{\mathbf{F C}}$} & \multirow{2}{*}{$\begin{array}{c}\text { WP, } \\
\%\end{array}$} & \multirow{2}{*}{$\underset{\%}{\mathbf{A W}}$} & \multicolumn{3}{|c|}{ Particle size distribution, } & \multirow[t]{2}{*}{ Texture } \\
\hline & & & & & Sand & Silt & clay & \\
\hline $0-15$ & 1.21 & 44.5 & 20.85 & 23.65 & 22.52 & 20.05 & 57.43 & Clay \\
\hline $15-30$ & 1.27 & 40.63 & 21.15 & 19.48 & 21.89 & 24.82 & 53.29 & Clay \\
\hline $30-45$ & 1.34 & 38.39 & 22.44 & 15.95 & 18.95 & 24.03 & 57.02 & Clay \\
\hline
\end{tabular}

FC, field capacity; WP, wilting point; AW, available water; $\boldsymbol{\rho}_{\mathbf{b}}$, bulk density 
Table (2): Chemical analysis of the experimental soil including anions, cations, EC, and $\mathrm{pH}$ at different soil depths

\begin{tabular}{|c|c|c|c|c|c|c|c|c|c|c|}
\hline \multirow{2}{*}{$\begin{array}{c}\text { Soil } \\
\text { depth, }\end{array}$} & \multirow{2}{*}{$\begin{array}{c}\mathrm{EC}, \\
\mathrm{dS} / \mathrm{m}^{-}\end{array}$} & \multirow{2}{*}{$\mathrm{pH}$} & \multicolumn{4}{|c|}{ Cations, meq/L } & \multicolumn{4}{c|}{ Anions, meq/L } \\
\cline { 4 - 11 } & & $\mathrm{Mg}^{++}$ & $\mathrm{Ca}^{++}$ & $\mathrm{K}^{+}$ & $\mathrm{Na}^{+}$ & $\mathrm{Co}_{3}^{--}$ & $\mathrm{HCo}^{-}$ & $\mathrm{Cl}^{-}$ & $\mathrm{So}_{4}^{--}$ \\
\hline $0-15$ & 2.99 & 8.13 & 11.64 & 7.91 & 0.31 & 12.31 & 0.01 & 6.9 & 13.2 & 12.06 \\
\hline $15-30$ & 2.95 & 8.17 & 8.91 & 7.32 & 0.28 & 13.05 & 0.03 & 9.7 & 9.6 & 10.23 \\
\hline $30-45$ & 2.98 & 8.21 & 9.12 & 6.01 & 0.34 & 14.3 & 0.03 & 10.8 & 9.2 & 9.74 \\
\hline
\end{tabular}

\section{Irrigation system and experimental layout}

A drip irrigation network (Fig. 1) was constructed to irrigate the experimental plots. The drip irrigation network consisted of a $2 \mathrm{hp}$ electrical engine that operates a $62 \mathrm{~L} / \mathrm{min}$ centrifugal pump to deliver water from irrigation channel or from the fish drainage water collecting basin. The network also included a fertigation unit, 120 mesh polyester screen filter, main and lateral lines, control valves and pressure gages. A 2 inch main line diameter made of PE was connected to the pumping unit to convey water to $16 \mathrm{~mm}$ PE lateral lines. Lateral lines were $25 \mathrm{~m}$ in length with $30 \mathrm{~cm}$ dripper spacing.

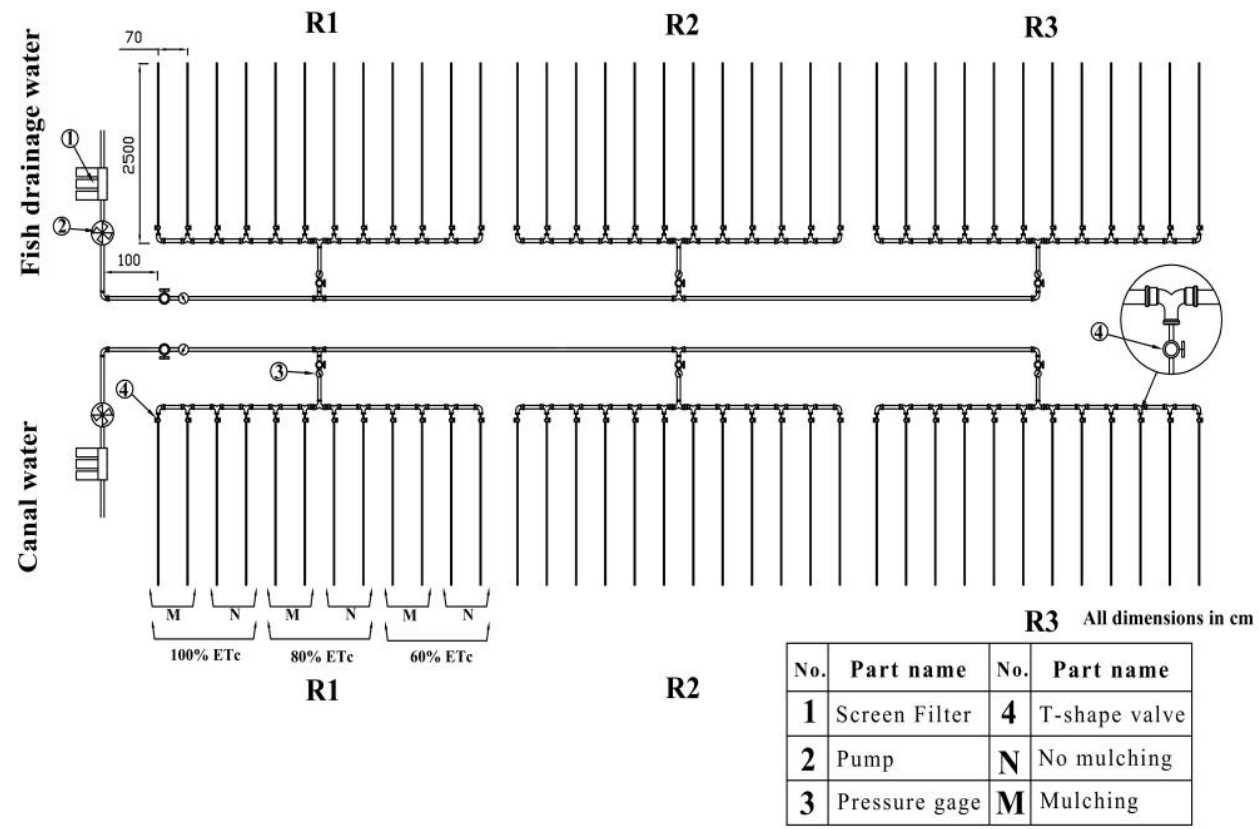

Fig. (1): Layout of drip irrigation system and the distribution of various treatments of the present study 
T-shape valves were installed at the start of each lateral line to control the amount of water delivered to each lateral line. Built in-line drippers of 4 $1 / \mathrm{h}$ were used for this network. To avoid delivering solid wastes and larger sediments to drip irrigation network, the beginning of water suction pipe was put in a cage covered by a double layers of net with very tiny holes having $0.5 \mathrm{~mm}$ diameter. The experiment soil was furrowed at $0.7 \mathrm{~m}$ spacing which was the same distance between lateral lines and the drippers were 0.3 apart.

\section{Irrigation Water Requirements}

Crop water requirements as illustrated in Fig (2) were calculated using CROPWAT v8 package based on Penman-Monteith formula. The potential evapotranspiration for cabbage was calculated taking into consideration the climatological data of the study site that collected by the Climate Station at Rice Research and Training Centre, Sakha, KafrElsheikh and Table (3) details the agro-climatological data. The total amount of seasonal irrigation water applied including the amount applied for planting was counted at $5378.8 \mathrm{~m}^{3} \mathrm{ha}^{-1}$.

Table (3): Agro-climatological data for the study area recorded at Sakha Research Station (latitude of $31.11^{\circ}$ and longitude of $30.95^{\circ}$ )

\begin{tabular}{|c|c|c|c|c|c|c|c|}
\hline Month & $\begin{array}{c}\mathbf{T}_{\max }, \\
{ }^{\circ} \mathbf{C}\end{array}$ & $\begin{array}{c}\mathbf{T}_{\min }, \\
{ }^{\circ} \mathrm{C}\end{array}$ & $\begin{array}{c}\mathrm{U}_{2} \\
(\mathrm{~km} / \mathrm{day})\end{array}$ & $\begin{array}{l}\text { RH } \\
(\%)\end{array}$ & $\begin{array}{l}\text { SH } \\
\text { (h) }\end{array}$ & $\begin{array}{c}\text { SR } \\
\text { Mj/mday }\end{array}$ & $\begin{array}{c}\text { ETo } \\
\text { (mm/day) }\end{array}$ \\
\hline April & 29.3 & 12.1 & 89.7 & 63.53 & 12.5 & 30.8 & 4.40 \\
\hline May & 29.6 & 16.7 & 99.3 & 56.05 & 13.0 & 31.5 & 5.62 \\
\hline June & 33.5 & 18.3 & 107.5 & 61.35 & 13.9 & 31.9 & 6.49 \\
\hline July & 33.0 & 19.7 & 102.0 & 65.10 & 13.7 & 32.7 & 6.24 \\
\hline August & 36.1 & 20.2 & 105.0 & 67.20 & 14.9 & 35.4 & 5.50 \\
\hline September & 31.6 & 20.2 & 98.0 & 60.47 & 13.6 & 33.7 & 4.60 \\
\hline October & 30.1 & 19.3 & 109.0 & 58.62 & 6.4 & 31.9 & 3.60 \\
\hline
\end{tabular}

$\mathrm{RH}$, relative humidity; $\mathrm{U}_{2}$, wind speed; $\mathrm{SH}$, sunshine hours; SR, solar radiation

\section{Fish farming system}

Two different fish basins designs were installed for this research study. Rectangular and circular fish basins were constructed for the fish farming system. The net dimensions of rectangular basins were $4 * 2 * 1.5 \mathrm{~m}$ (length * width * height) while the circular shape was $2 \mathrm{~m}$ diameter. 


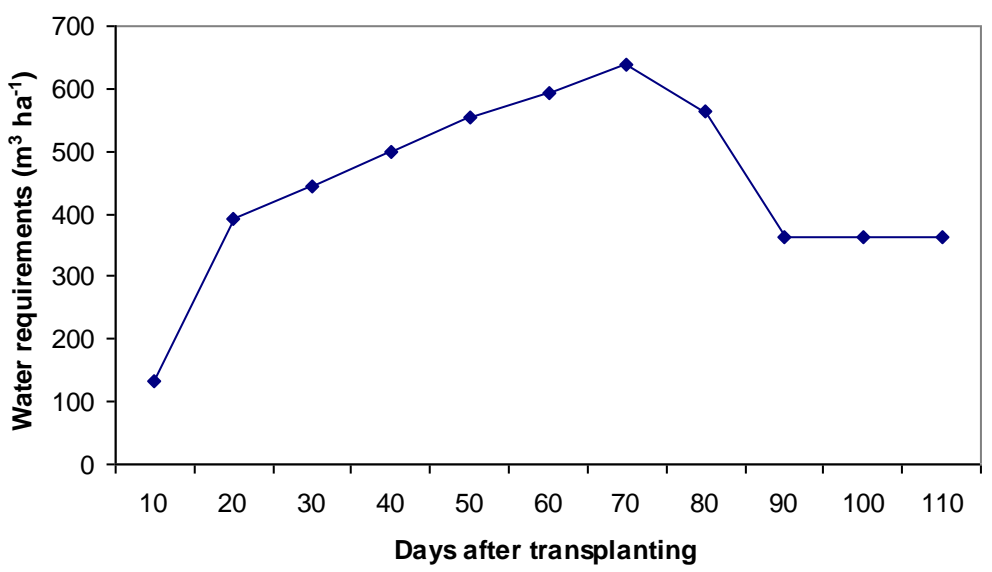

Fig. (2): Average monthly water applied to drip irrigated cabbage in 2018 summer season

Walls of both basins were constructed from bricks of $25 \mathrm{~cm}$ thickness and $25 \mathrm{~cm}$ of concrete was used for the bottom of basins to prevent water from percolation to the soil. Water in different basins was kept at $1 \mathrm{~m}$ height. A pipe of 2 inch diameter was installed at the bottom of each fish basin to drain water to the collecting basin. Every two days a third of each fish basin's water was replaced by fresh canal water. A $50 \mathrm{~m}^{2}$ basin was constructed to collect the drainage water from fish basins. Care was taken during pumping water from the collecting basin to avoid pumping solid wastes from nearby the base. The suction pipe was kept at the half of the water depth to be away from the sediments resulted from fish basins. A 2 inch pipe connected between the collecting basin and the drip irrigation network. Water level was remained at a constant height throughout the experiment. Samples of drainage water of fish basins were collected for analyzing and Table (4) lists the chemical analysis of these samples. $20 \mathrm{~g}$ per fish initial weight Nile tilapia was loaded for all basins at a density of 100 fish per cubic meter of water. The ingredients of fish feed were 4.96 $\%$ crude lipid, $28 \%$ crude protein and $5.08 \%$ crude fibber which produces a total energy of $4000 \mathrm{kcal} \mathrm{kg}^{-1}$. For the aeration purpose, fish basins were equipped with a 100 watts compressor which provides $110 \mathrm{~L} \mathrm{~min}^{-1}$ of air. The compressor was automatically adjusted to work 15 min per each hour. Ammonia was measured by an ammonia meter (Mi405 with a range 
of 0-9.99 mg. $\mathrm{L}^{-1}$ ) and dissolved oxygen was measured by an oxygen meter (range of 0-20 mg. $\mathrm{L}^{-1}$ ). Chemical analysis of fish basins drainage water was performed and different properties are detailed in Table (4).

Table (4): Chemical analysis of canal and fish basins drainage water

\begin{tabular}{|c|c|c|c|c|c|c|c|c|c|}
\hline & & \multicolumn{8}{|c|}{ Element } \\
\hline & & $\begin{array}{c}E C, \\
d S / m\end{array}$ & pH & $\begin{array}{l}\mathrm{NO}_{3}, \\
\mathrm{mg} / \mathrm{L}\end{array}$ & $\begin{array}{l}\mathrm{NO}_{2}, \\
\mathrm{mg} / \mathrm{L}\end{array}$ & $\begin{array}{l}\mathrm{NH}_{3}, \\
\mathrm{mg} / \mathrm{L}\end{array}$ & $\begin{array}{c}\text { TDS, } \\
\text { mg/L }\end{array}$ & $\begin{array}{c}\text { TSS, } \\
\text { Mg/L }\end{array}$ & $\begin{array}{r}\text { DO, } \\
\mathrm{mg} / \mathrm{L}\end{array}$ \\
\hline water & $\mathrm{CW}$ & 1.06 & 7.14 & 0.77 & 0.034 & 0.017 & 181 & 107 & 2.8 \\
\hline Source & DW & 1.15 & 7.65 & 187 & 0.24 & 0.23 & 392 & 173 & 3.76 \\
\hline
\end{tabular}

$\mathrm{CW}$, canal water ; DW, drainage water of fish basins; DO, dissolved Oxygen; TSS, total suspended solids; NO3, nitrate; NO2, nitrite; NH3, ammonia.

\section{Water productivity (WP)}

Water productivity $\left(\mathrm{kg} \mathrm{m}^{-3}\right)$ was determined as the ratio between cabbage head yield and the amount of applied water and was quantified according to Rodrigues and Pereira (2009) as follows:

$$
\mathrm{WP}=\mathrm{Y} / \mathrm{W} \text {, }
$$

Where: WP is water productivity in $\mathrm{kg} \mathrm{m}^{-3}, \mathrm{Y}$ is the cabbage total head yield in $\mathrm{Mg} \mathrm{ha}^{-1}$ and $\mathrm{W}$ is the amount of water applied in $\mathrm{m}^{3} \mathrm{ha}^{-1}$

\section{Nitrogen productivity (NP)}

Nitrogen productivity was determined as the ratio between the total cabbage yield in $\mathrm{kg}$ per hectare and the total amount of nitrogen fertilization applied for each treatment.

\section{Statistical Analysis:}

SAS software package (SAS Institute, 2003) was run to subject experimental data to statistical analysis. Least significant difference (LSD) at 5\% significance level was used to compare the means of various treatments. SAS also was used to quantify the coefficient of correlation.

\section{RESULTS AND DISCUSSION}

\section{a. Cabbage head and marketable yield}

Total cabbage head yield was significantly affected by the three investigated parameters including water regime, water type and mulching as detailed in Table (5). It is also shown that the interaction between water type, water regime and mulching was significant in all combinations of various parameters. Broadly, it is clear that the reuse of 
fish drainage water enhanced the total head and marketable yield of cabbage regardless the effect of the other two investigated parameters. At all irrigation regimes, reusing fish drainage water produced the highest head and marketable yield of cabbage. The highest values of cabbage head and marketable yield were 197.5 and $167.9 \mathrm{Mg} \mathrm{ha}^{-1}$ under the treatments of using fish drainage water, $100 \%$ ETc with mulching while the minimum values were 61.88 and $37.6 \mathrm{Mg} \mathrm{ha}^{-1}$ respectively with the combination of canal water, $60 \%$ ETc without mulching. The results in Table (6) also revealed that applying less water caused a decrease in head and marketable yield. Fish water increased yield by 1.7, 49.3 and $30.6 \%$ under 100, 80 and 60 ETc respectively. The combinations included $60 \%$ ETc gave less head and marketable yield among all treatments. From the above mentioned results the increase in head and marketable yield of cabbage may have been a result of additional nitrogen source that comes from fish effluents which is rich in nitrogen and other nutritional elements. These elements are essential for plant growth and motivate plants to perform various processes.

Table (5): Analysis of variance for the experimental variables on cabbage head yield

\begin{tabular}{|ccccc|}
\hline Source & D.F & Sum of squares & Mean square & F value \\
\hline Replicates & 2 & 10.079 & 5.04 & 3.39 \\
Water type (A) & 1 & 5019.9 & 5019.9 & $3381.8^{* *}$ \\
Error & 2 & 2.97 & 1.48 & \\
Water regime & 2 & 46391.7 & 23195.9 & $2419.4^{* *}$ \\
A*B & 2 & 157.9 & 78.95 & $8.24^{*}$ \\
Error & 8 & 76.69 & 9.59 & \\
Mulching (C) & 1 & 8289.8 & 8289.8 & $643.79^{* *}$ \\
A*C & 1 & 129.2 & 129.2 & $10.03^{* *}$ \\
B*C & 2 & 3845.1 & 1922.5 & $149.3 * *$ \\
A $^{*} \mathrm{~B} \mathrm{C}$ & 2 & 113.1 & 56.5 & $4.39^{*}$ \\
Error & 12 & 154.52 & 12.88 & \\
\hline
\end{tabular}


Table (6): Effect of water type, watering regime and mulching on cabbage head yield $\left(\mathrm{Mg} \mathrm{ha}^{-1}\right)$ and marketable head yield $\left(\mathrm{Mg} \mathrm{ha}^{-1}\right)$

\begin{tabular}{|c|c|c|c|c|c|}
\hline \multirow{3}{*}{$\begin{array}{c}\text { Water } \\
\text { type }\end{array}$} & \multirow{3}{*}{$\begin{array}{c}\text { Irrigation } \\
\text { regime }\end{array}$} & \multicolumn{2}{|c|}{ Head vield } & \multicolumn{2}{|c|}{ Marketable head vield } \\
\hline & & \multicolumn{4}{|c|}{ Mulching } \\
\hline & & With & without & With & without \\
\hline \multirow{3}{*}{$\begin{array}{l}\text { Canal } \\
\text { water }\end{array}$} & $100 \%$ ETc & 185.64 & 119 & 148.51 & 99.25 \\
\hline & $80 \%$ ETc & 85.68 & 66.64 & 59.98 & 39.51 \\
\hline & $60 \%$ ETc & 78.54 & 61.88 & 47.12 & 37.60 \\
\hline \multirow{3}{*}{$\begin{array}{c}\text { Fish } \\
\text { drainage } \\
\text { water }\end{array}$} & $100 \% \mathrm{ETc}$ & 197.54 & 145.18 & 167.91 & 101.15 \\
\hline & $80 \%$ ETc & 109.48 & 101.15 & 82.11 & 77.89 \\
\hline & $60 \%$ ETc & 102.34 & 83.30 & 71.64 & 54.15 \\
\hline Mean & & 126.5 & 96.19 & 92.21 & 68.26 \\
\hline
\end{tabular}

\section{b. Cabbage head diameter and height}

The results in Table (7) detail the effect of water type, watering regime and mulching on head diameter of cabbage. It is obvious that the optimum watering regime (100 ETc) motivated the growth rate of cabbage and thus produced larger head diameter. Applying less watering regime by 20 and $40 \%$ led to decrease cabbage head diameter by 31 and $41 \%$ comparing with $100 \%$ ETc in case of canal water with mulching and by 25 and $31 \%$ when using fish drainage water with mulching. Data had the same trend in case of no mulching used since higher cabbage head diameter was recorded with $100 \%$ ETc followed by $80 \%$ and $60 \%$ ETc. For both types of water full irrigation regime produced the highest cabbage head diameters with respective values of 29.6 and $28.7 \mathrm{~cm}$ for fish drainage water and canal water. When considering the influence of mulching, it is demonstrated that in all treatments set mulching in both cases of water type gave higher head diameters in comparison to the case of non mulched combinations. Furthermore it is clear that using mulching by rice straw motivate the cabbage growth in terms of head diameter. This can be relied on reducing evaporation from the wetted bulbs and the therefore increase water availability throughout the root zone that improve nutrients uptake. 
Head height had the same trend as the cabbage head diameter. The results showed that the highest cabbage head height was recorded with the treatment received $100 \mathrm{ETc}$, FW with mulching while the minimum values were obtained from the combination of CW plus $60 \%$ ETc without mulching.

Table (7): Effect of water type, watering regime and mulching on cabbage head diameter and height $(\mathrm{cm})$

\begin{tabular}{|c|c|c|c|c|c|}
\hline \multirow{3}{*}{$\begin{array}{c}\text { Water } \\
\text { type }\end{array}$} & \multirow{3}{*}{$\begin{array}{c}\text { Irrigation } \\
\text { regime }\end{array}$} & \multicolumn{2}{|c|}{ Head diameter } & \multicolumn{2}{|c|}{ Head height } \\
\hline & & \multicolumn{4}{|c|}{ Mulching } \\
\hline & & With & Without & With & Without \\
\hline \multirow{3}{*}{$\begin{array}{l}\text { Canal } \\
\text { water }\end{array}$} & $100 \%$ ETc & 28.7 & 20.2 & 22 & 20 \\
\hline & $80 \%$ ETc & 19.7 & 18.8 & 19.5 & 17.5 \\
\hline & $60 \%$ ETc & 16.9 & 14.9 & 17.5 & 17 \\
\hline \multirow{3}{*}{$\begin{array}{c}\text { Fish } \\
\text { drainage } \\
\text { water }\end{array}$} & $100 \%$ ETc & 29.6 & 22.3 & 25 & 22 \\
\hline & $80 \%$ ETc & 22.3 & 20.7 & 20 & 18 \\
\hline & $60 \%$ ETc & 20.7 & 19.1 & 18 & 17 \\
\hline Mean & & 22.98 & 19.33 & 20.33 & 18.58 \\
\hline
\end{tabular}

\section{c. Cabbage water productivity}

Water productivity (WP) was significantly impacted by irrigation water type, mulching and watering regime. Data detailed in Table (8) shows the statistical analysis of the effect of the three parameters used on cabbage total head yield showing that they significantly affected WP. It is seen in Table (9) that drainage water of fish basins produced higher WP in comparison to canal water since the highest WP of $36.7 \mathrm{~kg} \mathrm{~m}^{-3}$ was obtained with the treatment received fish drainage water, $100 \%$ ETc with mulching. Fish water increased yield by 16.1, 27.6 and $24.6 \%$ under 100, 80 and 60 ETc respectively. The results demonstrated that covering the wetted area by rice straw enhanced cabbage growth rate by reducing evaporation from the soil surface and therefore more availability of water for plants. Applying less water $(60 \% \mathrm{ETc})$ produced higher WP when comparing with $80 \%$ ETc that produced less WP. The minimum records of WP were obtained with the combination canal water, $80 \%$ ETc 
without mulching by rice straw. Although 100 ETc gave the highest records of cabbage yield, 60\% ETc is more advantageous when taking into consideration water scarcity as a determinant factor.

Table (8): Analysis of variance for the experimental variables on cabbage water productivity

\begin{tabular}{|ccccc|}
\hline Source & D.F & Sum of squares & Mean square & F value \\
\hline Replicates & 2 & 0.507 & 0.254 & 1.419 \\
Water type & 1 & 300.09 & 300.09 & $1679.47 * *$ \\
Error & 2 & 0.357 & 0.179 & \\
Water regime & 2 & 486.53 & 243.26 & $497.67 * *$ \\
A*B & 2 & 22.66 & 11.33 & $23.18^{* *}$ \\
Error & 8 & 3.91 & 0.489 & \\
Mulching (C) & 1 & 390.72 & 390.72 & $597.32^{* *}$ \\
A*C & 1 & 4.93 & 4.93 & $7.53^{* *}$ \\
B*C & 2 & 97.97 & 48.98 & $74.88^{* *}$ \\
A*B*C & 2 & 5.32 & 2.66 & $4.07 *$ \\
Error & 12 & 7.85 & 0.654 & \\
\hline
\end{tabular}

Table (9) Effect of water type, watering regime and mulching on water productivity of cabbage $\left(\mathrm{kg} \mathrm{m}^{-3}\right)$

\begin{tabular}{|c|c|c|c|c|}
\hline \multirow{3}{*}{ Water type } & \multirow{3}{*}{$\begin{array}{c}\text { Irrigation } \\
\text { regime }\end{array}$} & \multicolumn{2}{|c|}{ WP $\left(\mathrm{kg} \mathrm{m}^{-3}\right)$} & \multirow{3}{*}{ Mean } \\
\hline & & \multicolumn{2}{|c|}{ Mulching } & \\
\hline & & With & without & \\
\hline \multirow{3}{*}{ Canal water } & $100 \%$ Etc & 34.5 & 22.1 & 28.3 \\
\hline & $80 \%$ Etc & 19.87 & $\underline{15.5}$ & 17.69 \\
\hline & $60 \%$ Etc & 24.33 & 19.17 & 21.75 \\
\hline \multirow{3}{*}{$\begin{array}{c}\text { Fish } \\
\text { drainage } \\
\text { water }\end{array}$} & $100 \%$ Etc & $\underline{36.7}$ & 26.9 & 31.8 \\
\hline & $80 \%$ Etc & 25.38 & 23.5 & 24.44 \\
\hline & $60 \%$ Etc & 31.83 & 25.83 & 28.83 \\
\hline Mean & & 23.5 & 17.9 & \\
\hline
\end{tabular}




\section{d. Nitrogen productivity}

Data illustrated in Fig. (3) and depicted in Table (10) show the effect of water type, mulching with rice straw and watering regime on nitrogen productivity of cabbage crop. It is seen that the average values of nitrogen productivity were remarkably enhanced by irrigation with fish basins drainage water.

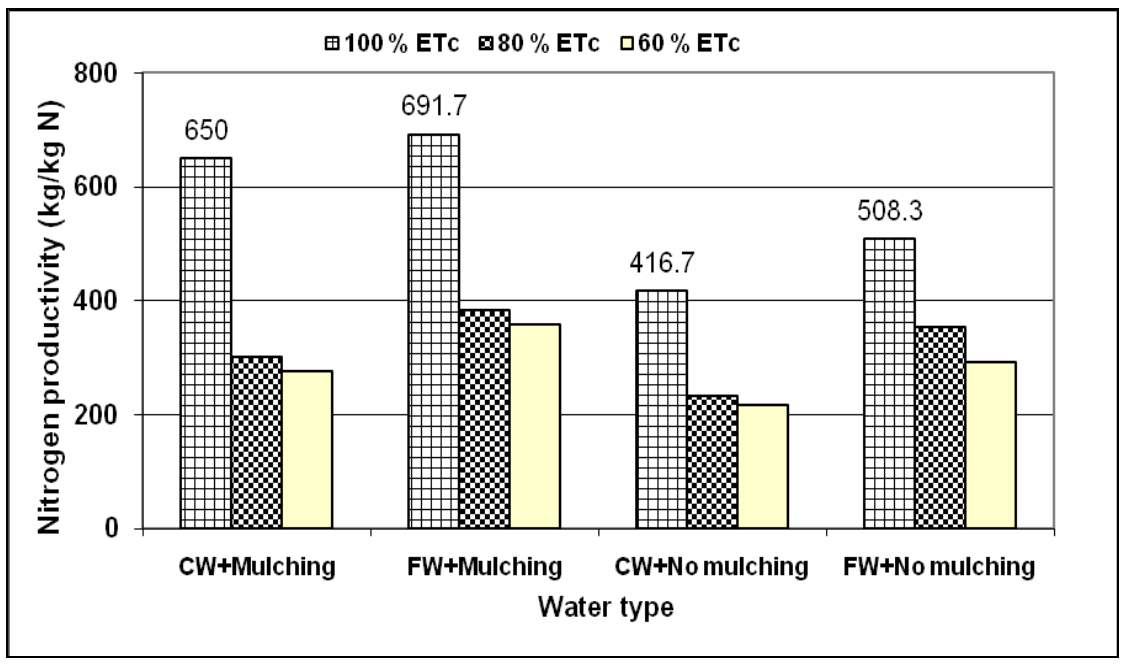

Fig (3): Effect of water type, watering regime and mulching on nitrogen productivity of cabbage

Table (10): Effect of water type, watering regime and mulching on nitrogen productivity of cabbage $(\mathrm{kg} / \mathrm{kg} \mathrm{N})$

\begin{tabular}{ccccc}
\hline \multirow{2}{*}{ Water type } & \multirow{2}{*}{$\begin{array}{c}\text { Irrigation } \\
\text { regime }\end{array}$} & \multicolumn{2}{c}{ Wulching } & \multirow{2}{*}{ Mean } \\
\cline { 3 - 4 } & $100 \%$ Etc & 650 & 416.7 & 533.4 \\
\multirow{2}{*}{$\mathrm{CW}$} & $80 \%$ Etc & 300 & 233.3 & 266.7 \\
& $60 \%$ Etc & 275 & $\mathbf{2 1 6 . 7}$ & 245.9 \\
\hline \multirow{2}{*}{ DW } & $100 \%$ Etc & $\mathbf{6 9 1 . 7}$ & 508.3 & 600 \\
& $80 \%$ Etc & 383.3 & 354.2 & 368.8 \\
\hline \multirow{2}{*}{ Mean } & $60 \%$ Etc & 358.3 & 291.7 & 325 \\
\hline
\end{tabular}

DW, fish drainage water; $\mathrm{CW}$, canal water 
Mulching also encouraged nitrogen productivity since higher values were obtained with the combination included mulching with rice straw. The highest record of nitrogen productivity of $691.7 \mathrm{~kg} / \mathrm{kg}$ nitrogen was obtained from the treatment received fish drainage water, $100 \%$ ETc with mulching while the minimum value of $216.7 \mathrm{~kg} / \mathrm{kg}$ nitrogen was recorded with the combination canal water, $60 \%$ ETc without mulching. The obtained results demonstrated that fish basins drainage water would be a good source of water and nitrogen for the irrigation of leafy crops such as cabbage and lettuce. It is also obvious that applying less water to cabbage significantly decreased cabbage properties since the surface area for evapotranspiration is larger.

\section{CONCLUSION}

This research attempted to assess the possibility of reusing the drainage water of fish farming systems to irrigate cabbage crop. The study was based on the hypothesis that the drainage water of fish farming system could be a potential alternative safe source of irrigation water and nitrogen. The results of this research obviously indicated that the reuse of drainage water of fish farming systems can increase head yield, water productivity, nitrogen productivity and other components of cabbage yield. The results further showed that mulching not only motivate cabbage growth by increasing the availability of water in the root zone but also improve nutrients uptake and thus produce higher head and marketable yield. The novel idea presented her is the combination between watering regime, mulching by rice straw and using fish drainage water with drip irrigation system to have better irrigation and fertilization management. Moreover, the study showed the effectiveness of using fish drainage water as a source of nitrogen and other nutrients necessary for cabbage growth.

\section{REFERENCES}

Abdelraouf, R.E.; E. Hoballah, and M.A. Horia (2014). Reuse of drainage water of fish ponds in soybean cultivation under sprinkler irrigation system. International Journal of Plant and Soil Science, 3: 644-658. 
Attafy, T.M. and A.M. Elsbaay (2017). Integrated management of fish (Nile Tilapia) and leaf vegetable crop (head lettuce) culture under drip irrigation system. Misr J. Agric. Engi., 35 (1): 105-124.

Lin, C.K. and Y. Yi (2003). Minimizing environmental impacts of fresh water aquaculture and reuse of pond effluents and mud. Aquaculture, 226: 57-68.

Masser, M.P.; J. Rakocy and T.M. Losordo (1992). Recirculating aquaculture tank production systems management of recirculating systems. South Reg. Aquac. Cent. 1-12. Doi: 10.1016/S00028223(99)00856-1.

Okasha, E.M.; A. Ramadan; M.A. El-Shawadfy and H.H. Tarabye (2016). Integrated management for drainage water of fish ponds in agriculture using sprinkler irrigation system. Research J. of Pharmaceutical, Biology and Chemical Sciences, 7(3):595-605.

Porrello, S.; M. Lenzi; G. Ferrari; E. Persia; F. Savelli and P. Tomassetti (2005). Loading of nutrient from a land based fish farm (Orbetello, Italy) at different times. Aquaculture International, 13: 97-108.

Rodrigues, G.C. and L.S., Pereira (2009). Assessing economic impacts of deficit irrigation as related to water productivity and water costs. Biosystems Eng., 103: 536-551.

SAS Institute (2003). SAS User's Guide: Version 9.1. SAS Institute Inc., Cary, NC.

Sikawa, D.C. and A. Yakupitiyage (2010). The hydroponic production of lettuce (Lactuca Sativa L) by using hybrid catfish (Clarias macrocephalus $x$ C.gariepinus) pond water: Potential and constraints.

Wood, C.W.; B.M. Meso; K.L. Ververica and N. Karanja (2001). Kenya investigation of pond effluent for crops yields recommendations. Aquanews, 16: 13-15.

Yi, Y.; C.K. Lin and J.S. Diana (2003). Hybrid catfish (Clarias macrocephalus $x$ Clarias gariepinus) and Nile tilapia (Oreochromis 
niloticus) culture in an integrated pen-cum-pond system: growth and performance and nutrient budgets. Aquaculture, 217: 395-408.

\section{الملخص العربي \\ تأثير استخدام مياه صرف احواض السمك والتغطية ومعدل اضافة المياه على التى التهي خواص محصول الكرنب تحت نظام الرى بالتنقيط عادل هلال المتولى * و مى محمد عامر**}

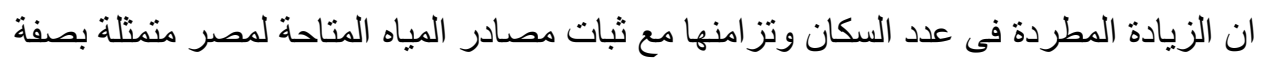

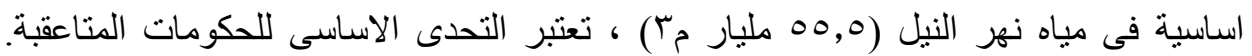

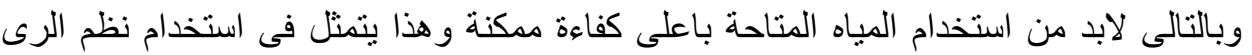

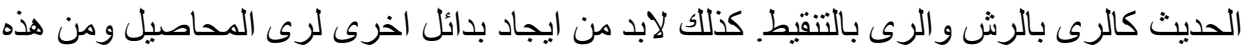

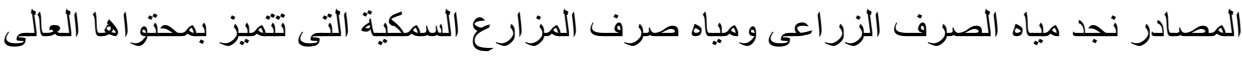

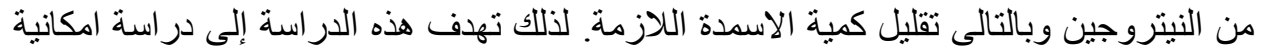

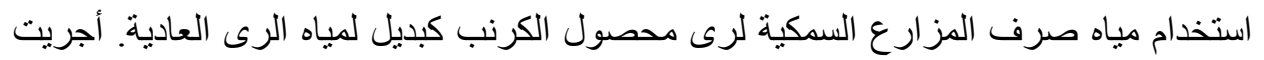

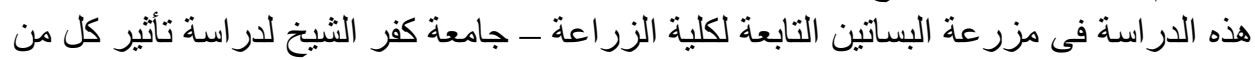

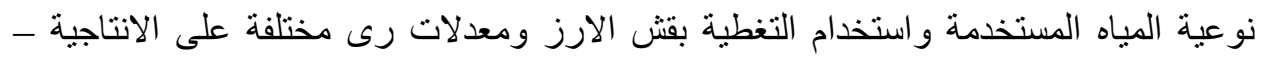

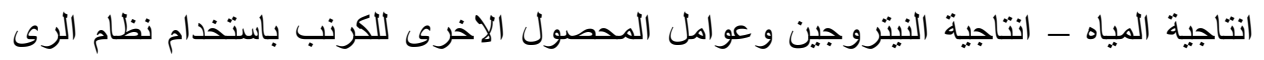
بالتنقيط وكانت عو امل الدرسة كالتالى:

نوعية المياه : مياه الرى العادية - مياه صرف مز ارع السمك

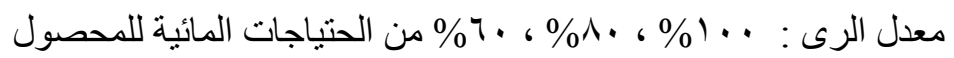
نظم التغطية : تغطية باستخدام قش الارز - بدون تغطية

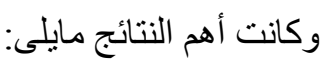
بصفة عامة وبغض النظر عن نأثثر التغطية ومعدل اضافة المباه فأن الرى بمياه

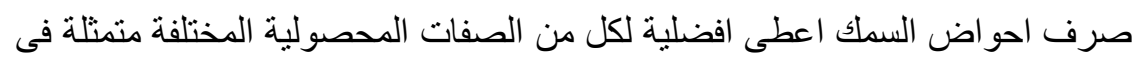
الانتاجية ، قطر الر أس للكرنب ، ارتفاع الر أس وكذللك انتاجية الوحدة من المياه.

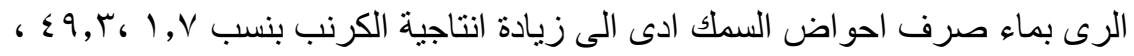

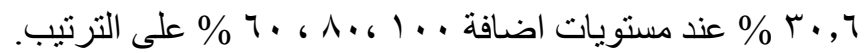

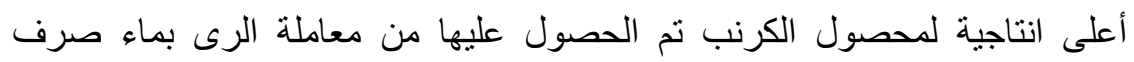

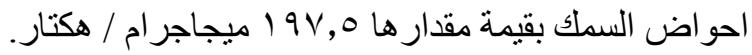

* أستاذ مساعد الهندسة الزراعية ـ قسم الهندسة الزراعية ـ كلية الزراعة - جاعزة جامعة طنطا ـ مصر.

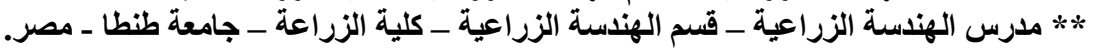




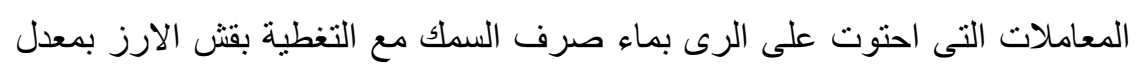

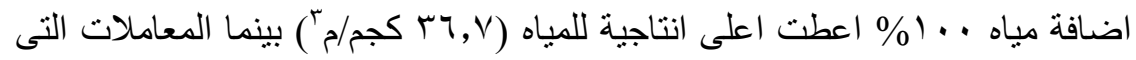

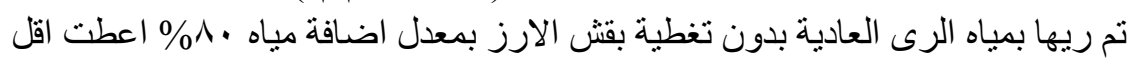
انتاجية للمياه (10,0 1 كجم/م"r).

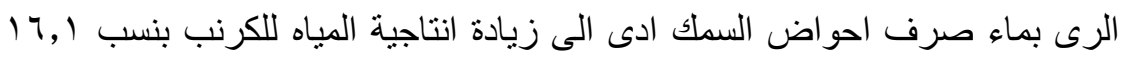

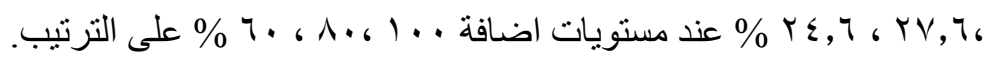

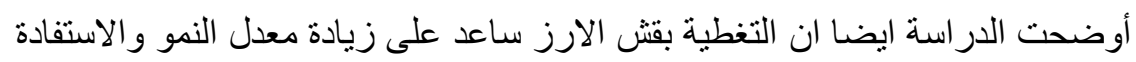

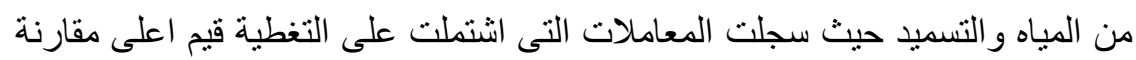
بالمعاملات التى لا تحنوى على تغطية.

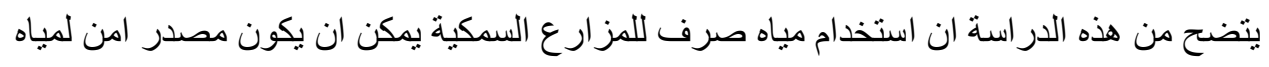

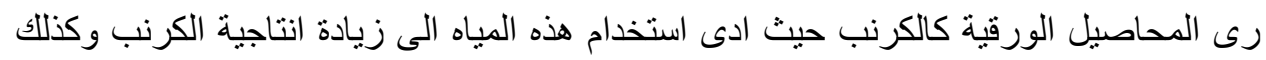

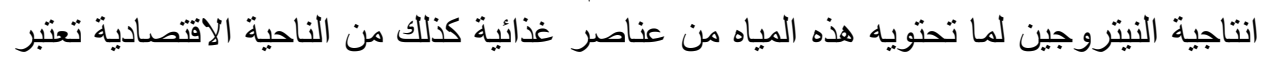
طريقة جيدة وذات عائد عند النظر للتوفير فى كميات الاسمدة المستخدمة. 